\title{
PENGARUH PENGGUNAAN MEDIA AUDIO VISUAL \\ TERHADAP KETERAMPILAN MEMBACA PUISI SISWA KELAS VIII SMPS RAUDHATUL FUQARA'
}

\author{
oleh \\ Mauliza Yanti, Sayni Nasrah*, Rani Ardesi Pratiwi \\ *Dosen Program Studi Pendidikan Bahasa Indonesia, FT Universitas Malikussaleh \\ surel: sayni.nasrah@unimal.ac.id
}

\begin{abstract}
ABSTRAK
Penelitian ini bertujuan untuk mendeskripsikan pengaruh penggunaan media audio visual terhadap keterampilan membaca puisi siswa SMPS Raudhatul Fuqara'. Masalah dalam penelitian ini adalah rendahnya keterampilan membaca puisi pada siswa SMPS Raudhatul Fuqara'. Penelitian ini menggunakan pendekatan kuantitatif dengan metode eksperimen rancangan penelitian yang digunakan yaitu control group pre-test post-test design. Penelitian ini menggunakan teknik purposive Sampling dengan subjek penelitian semua siswa kelas VIII/E yang dijadikan kelas kontrol dan kelas VIII/D sebagai kelas eksperimen, dengan jumlah sebanyak 44 siswa. Metode pengumpulan data menggunakan instrumen tes hasil belajar. Analisis data menggunakan uji t. Hasil penelitian menunjukan ada pengaruh yang signifikan dalam penggunaan media audio visual terhadap keterampilan membaca puisi pada siswa kelas VIII SMPS Raudhatul Fuqara'.
\end{abstract}

Kata Kunci: Pengaruh, Media Audiovisual, Membaca Puisi. 


\section{PENDAHULUAN}

Penelitian ini berjudul "Pengaruh Penggunaan Media Audio Visual Terhadap Keterampilan Membaca Puisi Siswa Kelas VIII SMPS Raudhatul Fuqara",. Penelitian ini ditunjukkan untuk melihat ada atau tidaknya pengaruh media pembelajaran audio visual yang dianggap mampu meningkatkan keterampilan membaca puisi siswa. Sebagaimana kenyataan di lapangan dilihat saat penulis melaksanakan proses pembelajaran. Hasil belajar siswa dalam kegiatan membaca puisi masih tergolong rendah. Sebagian siswa masih belum bisa mengungkapkan ide atau gagasan penyair dalam puisinya dengan baik. Memahami puisi, berarti seseorang harus mampu menemukan tema atau permasalahan yang diangkat, perasaan penulis, dan amanat yang disampaikan. Cara untuk mencapai pemahaman tersebut, seseorang harus terlebih dahulu mengetahui latar belakang penulis. Membaca atau mendengar pembacaan puisi dengan penghayatan yang sungguh-sungguh dapat memberikan pemahaman secara mendalam terhadap puisi yang dibacakan, merasakan apa yang ditulis, mampu menyerap nilai-nilai yang terkandung dalam puisi, dan mampu menghargai puisi sebagai karya seni dengan keindahan serta kelemahannya.

Media audio visual merupakan media yang tepat untuk menunjang hasil belajar siswa pada pembelajaran bahasa Indonesia khusunya dalam keterampilan membaca puisi. Media tersebuat dapat diterapkan sebagai contoh atau gambaran pembacaan puisi melalui tayangan sebuah video yang menayangkan pembacaan puisi yang dibaca oleh penyair maupun seseorang yang pakar dalam bidang baca puisi.

Berdasarkan observasi awal yang penulis lakukan di SMPS Raudhatul Fuqara' pada bulan Januari tahun 2019 didapatkan beberapa permasalah dalam membaca puisi. Pertama, kurangnya kreatifitas guru dalam menggunakan media pembelajaran. Kedua, siswa cenderung bosan dalam kelas karena belajar masih secara konvensional tidak ada sama sekali perubahan. Ketiga, keterampilan membaca puisi sudah sangat melemah didalam pembelajaran bahasa Indonesia, siswa masih kurang minat khususnya pada materi puisi, banyak siswa yang masih belum bisa membaca puisi dengan lafal, tekanan, ekspresi, dan intonasi yang sesuai dengan isi puisi. Hal ini disebabkan karena guru belum dapat memanfaatkan fasilitas yang tersedia di sekolah, seperti LCD dan speaker. Pemanfaatan fasilitas ini berkaitan dengan penggunaan media pembelajaran yang tepat untuk pembelajaran membaca puisi. Dalam praktiknya, siswa membutuhkan sebuah contoh nyata yang baik sebagai ilustrasi sehingga siswa dapat memiliki gambaran tentang bagaimana membaca puisi yang baik. Oleh karena itu, guru hendaknya dapat memilih media pembelajaran yang tepat, seperti media audio visual.

Berdasarkan uraian tersebut dibutuhkan perbaikan yang dapat mendorong dan memberi kemudahan bagi siswa dalam keterampilan membaca puisi. oleh karena itu perlu, perlu diadakan penelitian lebih lanjut dalam meningkatkan keterampilan membaca puisi siswa.

Pengertian media dalam pembelajaran cenderung diartikan sebagai alat-alat grafis, photografis, atau elektronis untuk menangkap, memproses dan menyusun kembali informasi, Media pembelajaran meliputi alat yang secara fisik digunakan untuk menyampaikan isi materi pengajaran, antara lain buku, tape recorder, kaset, camera, video rekaman, film, slide (gambar bingkai), foto gambar, grafik, televisi, dan computer (Arsyad dalam Farisah, 2017:8). Batasan mengenai pengertian media sangat luas, namun dalam hal ini dibatasi pada media dalam proses pembelajaran. Istilah media juga sering dilekatkan pada kata massa, mass media, yang perwujudannya dapat dilihat dalam bentuk surat kabar, majalah, radio, video, televisi, internet \& intranet, dan sebagainya (Yaumi 2018:5).

Media juga berfungsi untuk intruksional, dimana informasi yang terdapat dalam media itu harus melibatkan siswa baik dalam benak atau mental maupun dalam bentuk aktifitas yang nyata sehingga pembelajaran dapat terjadi. Materi harus dirancang secara lebih sistematis dan psikologis dilihat dari segi prinsip-prinsip belajar agar dapat menyiapkan intruksi yang efektif. Media pembelajaran berfungsi untuk menimbulkan kegairahan belajar, memungkinkan interaksi yang lebih langsung antara anak didik dengan lingkungan dan kenyataan, serta memungkinkan anak didik belajar sendiri-sendiri menurut kemampuan 
dan minatnya (Sadiman dalam Nugroho, 2016:32).

Media audio visual merupakan salah satu media yang tepat dalam pembelajaran karena media audio visual dapat menarik perhatian siswa dan pesan atu materi yang disampaikan dapat dilihat dan didengar langsung oleh siswa, apalagi jika siswa tersebut terlibat langsung dalam penggunaan dan pemanfaatan media audio visual tersebut. Penggunaan media pembelajaran diharapkan dapat menimbulkan dampak positif dalam proses pembelajaran.

Dalam hal ini media yang tepat digunakan dalam pembelajaran ketrampilan membaca puisi adalah media audio visual yang telah tergabung dengan suara dan gambar didalamnya, media dalam bentuk audio visual yang di pilih peneliti diharapkan dapat meningkatkan hasil belajar siswa. Audio visual digunakan untuk membawa lingkungan keruangan kelas dalam bentuk video yang diputar dikelas. Audio visual dapat digunakan berulang kali sesuai dengan kebutuhan, saat guru ingin memberikan informasi atau penguatan mengenai materi yang sedang dipelajari video dapat dihentikan atau diputar kembali.

Media audio visual dapat memotivasi siswa dalam memahami konsep yang sedang dipelajari. Pada tahap titik lanjut, media dapat membantu guru untuk mengulangi lagi bagian yang kurang jelas bagi siswa, guru mampu mengaitkan konsep materi pelajaran yang diajarkan dengan pengalaman siswa sehari-hari sehingga kemungkinan timbulnya persepsi yang berbeda-beda oleh anak didik semakin kecil, motivasi siswa untuk belajar menjadi meningkat sehingga hasil belajar pun meningkat.

Berdasarkan penjelasan tersebut, media pembelajaran audio visual dapat dinyatakan sebagai alat yang secara fisik digunakan untuk menyampaikan isi materi pengajaran yang berupa perangkat keras yang memberikan penekanan pada pengalaman konkrit atau nonverbal melalui mata dan telinga dalam proses belajar. Media audio visual dapat diklasifikasikan sebagai media video. Video tersebut dapat diputar dengan bantuan perangkat keras dan perangkat lunak. Video atau gambar hidup merupakan gambar-gambar dalam frame dimana frame demi frame di proyeksikan melalui lensa proyektor secara mekanis sehingga pada layar terlihat gambar hidup. Media ini pada umumnya digunakan untuk tujuan-tujuan hiburan, dokumentasi, dan pendidikan. Video yang dipergunakan dalam kelas adalah video pembelajaran bukan semata-mata sebagai hiburan belaka. Video memang wajar digunakan dalam kelas, karena bukan saja memberikan fakta-fakta, tetapi juga menjawab persoalan dan untuk mengerti tentang materi yang akan dipelajari.

\section{LANDASAN TEORI}

Pengertian media dalam pembelajaran cenderung diartikan sebagai alat-alat grafis, photografis, atau elektronis untuk menangkap, memproses dan menyusun kembali informasi, Media pembelajaran meliputi alat yang secara fisik digunakan untuk menyampaikan isi materi pengajaran, antara lain buku, tape recorder, kaset, camera, video rekaman, film, slide (gambar bingkai), foto gambar, grafik, televisi, dan computer (Arsyad dalam Farisah, 2017:8). Batasan mengenai pengertian media sangat luas, namun dalam hal ini dibatasi pada media dalam proses pembelajaran. Istilah media juga sering dilekatkan pada kata massa, mass media, yang perwujudannya dapat dilihat dalam bentuk surat kabar, majalah, radio, video, televisi, internet \& intranet, dan sebagainya (Yaumi 2018:5).

Media juga berfungsi untuk intruksional, dimana informasi yang terdapat dalam media itu harus melibatkan siswa baik dalam benak atau mental maupun dalam bentuk aktifitas yang nyata sehingga pembelajaran dapat terjadi. Materi harus dirancang secara lebih sistematis dan psikologis dilihat dari segi prinsip-prinsip belajar agar dapat menyiapkan intruksi yang efektif. Media pembelajaran berfungsi untuk menimbulkan kegairahan belaja

\section{METODE PENELITIAN}

Penelitian ini menekankan fenomena-fenomena obyektif dan dikaji secara kuantitatif. Penelitian kuantitatif adalah penelitian yang dilakukan dengan angka-angka, mulai dari pengumpulan data, pengolahan data, penafsiran data serta pembahasan hasil penelitian (Arikunto, 2013:27).

Metode yang digunakan dalam penelitian ini adalah metode eksperimen 
dengan rancangan control group pre-testpost-test design. Peneliti ingin mengetahui pengaruh penggunaan media audio visual terhadap keterampilan membaca puisi dengan mengetahui secara pasti pengaruh penggunaan media audiovisual terhadap membaca puisi siswa di dua kelompok sampel yang dijadikan penelitian. Berikut adalah tabel rancangan eksperimen menurut Sugiyono (2017:76).

Populasi adalah keseluruhan individu yang bersifat general atau umum yang mempunyai karakteristik yang cenderung sama. Menurut Sugiyono (2017:80) menyatakan bahwa populasi adalah wilayah generalisasi yang terdiri atas: obyek/subyek yang mempunyai kualitas dan karakteristik tertentu yang diterapkan oleh peneliti untuk dipelajardan kemudian ditarik kesimpulannya. Adapun populasi dalam penelitian ini adalah siswa kelas VIII SMPS Raudharul Fuqara' yang terdiri dari 5 kelas dan berjumlah 134 siswa.

Sampel adalah bagian dari jumlah dan karakteristik yang dimiliki oleh populasi tersebut. Bila populasi besar, dan peneliti tidak mungkin mempelajari semua yang ada pada populasi, maka peneliti dapat menggunakan sampel dari populasi itu. Sugiyono (2017:8) menyatakan bahwa sampel adalah bagian dari jumlah dan karakteristik yang dimiliki oleh populasi tersebut.

Berdasarkan jumlah populasi yang ada maka sampel dalam penelitian ini di ambil dua kelas. Satu kelas sebagai kelas eksperimen dan satu kelas sebagai kelas kontrol. penetapan nilai didua kelas tersebut dengan cara melihat nilai paling rendah yang diperoleh oleh siswa pada mata pelajaran Bahasa Indonesia. Sampel pada penelitian ini adalah siswa kelas VIII/D sebagai kelas eksperimen yang menggunakan media audio visual. Kelas VIII/E sebagai kelas kontrol tanpa menggunakan media audio visual. Sampel dalam penelitian ini diambil dengan teknik Purposive sampling. Pada teknik Purposive sampling pengambilan sampel dilakukan dengan mengambil seluruh siswa di kelas tertentu sebagai sampel penelitian namun dengan alasan tertentu, peneliti memilih kelas VIII/D dan VIII/E untuk dijadikan kelas eksperimen dan kelas kontrol karena dua kelas tersebut mendapatkan nilai paling rendah.
Sugiyono, 2017:244 menyatakan bahwa teknik analisis data adalah proses mencari dan menyusun secara sistematis data yang diperoleh dari hasil wawancara, catatan lapangan, dan dokumentasi, dengan cara mengorganisasikan data kedalam katagori, menjabarkan kedalam unit-unit, melakukan sintesa, menyusun kedalam pola, memilih mana yang penting dan yang akan dipelajari, dan membuat kesimpulan sihingga mudah difahami oleh diri sendiri dan orang lain. Data dan keterangan-keterangan tersebut dapat diperoleh dengan menggunakan teknik pengumpulan data yang sesuai dengan permasalahan yang akan diteliti. Data yang diperoleh dianalisis dengan langkah-langkah sebagai berikut. (1) Menyimak dan memberikan skor, pada setiap aspek lafal, tekanan, intonasi, dan ekspresi. (2) Menabulasikan rata-rata skor yang diperoleh siswa dalam kegiatan pretes dan postes membaca puisi baik peraspek maupun secara total. (3) Melakukan uji T-Tes menggunakan SPSS versi 18 terhadap data-data pretes dan postes kelompok eksperimen dan kelompok kontrol pada kegiatan membaca puisi. Namun, sebelum melakukan uji $\mathrm{T}$ - Tes, terlebih dahulu harus melakukan uji normalitas dan uji homogenitas. (4) Setelah dilakukan pengujian populasi data dengan menggunakan normalitas dan homogenitas, apabila data populasi berdistribusi normal dan data populasi homogen, maka dilakukan uji t. Uji hipotesis ini digunakan untuk mengetahui adanya pengaruh penggunaan media audio visual terhadap keterampilan membaca puisi siswa dan tidak menggunakan media audio visual. (5) Mendeskripsikan pengaruh media audio visual terhadap kemampuan membaca puisi berdasarkan dari hasil uji T-Tes yang dilakukan menggunakan program SPSS versi 18, dan dari hasil uji hipotesis konseptual dengan menggunakan pasangan hipotesis statistik dan kriteria uji.

\section{HASIL PENELITIAN}

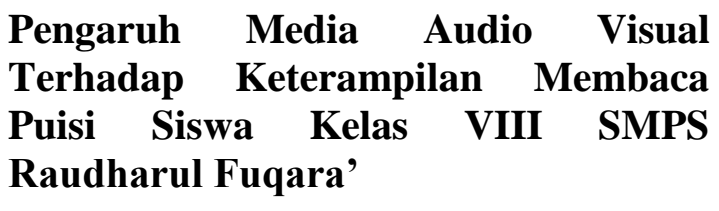

Penelitian ini dilakukan di SMPS Raudhatul Fuqara' yang terletak dikawasan jalan Jl. Cut Meutia, Desa Tumpok Mesjid, kec. Paya 
Bakong. Penelitian ini dilaksanakan di kelas VIII/D sebagai kelas eksperimen dan di kelas VIII/E sebagai kelas kontrol pada tanggal 28 September Sampai 5 Oktober 2020. Penelitian ini bertujuan untuk mengetahui bagaimana pengaruh penggunaan media audio visual terhadap keterampilan membaca puisi siswa kelas VIII SMPS Raudharul Fuqara'.

Materi pelajaran Bahasa Indonesia yang diajarkan pada penelitian ini adalah materi membaca puisi. Pada proses pembelajaran, kedua kelompok mendapatkan perlakuan yang berbeda. Kelompok eksperimen dengan pembelajaran menggunakan media audiovisual, sedangkan kelompok kontrol tanpa media pembelajaran. Berdasarkan hasil penelitian yang telah dilakukan pada kelompok eksperimen dan kelompok kontrol, diperoleh hasil tes akhir (post test) pada kedua kelompok. Adapun hasil data yang peneliti peroleh dianalisis dan ditampilkan dalam bentuk tabel dan pendskripsiannya. Hasil akhir dari data yang telah diproses bertujuan untuk membuktikan apakah terdapat perbedaan yang signifikan antara kelompok kontrol dan kelompok eksperimen setelah media audiovisual dalam hal ini video diterapkan dalam pembelajaran membaca puisi. Instrumen penelitian yang digunakan dalam penelitian ini adalah tes yang berupa praktik membaca puisi di depan kelas.

\section{Deskripsi Proses Pembelajaran Kelas Kontrol Menggunakan Metode Konvensional}

Objek pada penelitian ini adalah siswa kelas VIII/E yang menjadi kelas kontrol dengan jumlah 22 siswa. Pada kelas kontrol pre-test dilakukan pada tanggal 28 September 2020 pada hari Selasa, pukul 08.00 sampai 09.00 pagi hari. Sebelum dilakukan pre-test peneliti bertanya kepada siswa tentang apa itu puisi. Kemudian, peneliti memancing siswa dengan menanyakan tentang puisi apa saja yang pernah mereka baca dan dengarkan, kemudian peneliti membagikan kelompok untuk melakukan pembacaan puisi yang disediakan oleh peneliti. Tujuan diterapkan pre-test untuk mengetahui keterampilan awal siswa dalam membaca puisi sebelum materi membaca puisi diajarkan. Pada saat pre-test berlangsung siswa terlihat kebingungan dalam proses membaca, dikarenakan siswa kurang mengetahui bagaimana cara membaca puisi yang benar dan tepat sehingga pada saat membaca siswa tidak memperhatikan apa saja hal penting yang harus di pahami dalam proses membaca puisi tersebut. Setelah melakukan proses pre-test membaca puisi di depan kelas kemudian peneliti memberikan skor kriteria nilai hasil pre-test siswa dan dimasukkan ke dalam tabel nilai.

Peneliti mencari nilai rata-rata menggunakan SPSS versi 18, cara lain untuk mencari nilai rata-rata siswa dengan menggunakan rumus:

$$
\bar{X}=\frac{1}{n} \sum_{i=1}^{n} x i
$$

Keterangan:

$\bar{x}=$ rata-rata hitung

$x i=$ nilai sampel ke- $i$

$n=$ jumlah sampel

Dapat dilihat nilai rata-rata dari pre-test kelas kontrol adalah 65,68 hasil pre-test yang diperoleh siswa masih rendah. Atas dasar nilai pre-test tersebut, diterapkanlah metode konvensional pada kelas kontrol ini untuk melihat apakah terjadi peningkatan nilai hasil belajar terhadap keterampilan membaca puisi dengan menggunakan metode konvensional.

Selanjutnya, proses pembelajaran pada kelas kontrol dengan metode konvensional dilakukan pada tanggal 29 September 2020 pada hari Selasa, pukul 10.00 sampai dengan pukul 11.30. Pada saat proses pembelajaran berlangsung hanya ada beberapa siswa yang mengerti tentang membaca puisi. Bahkan ada yang belum pernah mendengar sama sekali tentang bagaimana cara atau proses membaca puisi yang benar dan tepat. Peneliti mengajarkan proses membaca puisi dan memberikan contoh kepada siswa dengan menjelaskan materinya saja di depan kelas. Peneliti memberikan contoh puisi yang akan dibacakan di depan kelas dengan puisi yang terdapat pada buku Bahasa Indonesia, kemudian siswa memperhatikan dengan seksama dan mencoba mempraktekkannya kembali membaca puisi yang sudah diberikan dengan memperhatikan unsurunsur pembacaan puisi yang benar dan tepat meliputi vocal, irama, intonasi, dan ekspresi dalam sebuah puisi. 
Setelah pre-test dan proses pembelajaran telah dilakukan. Kemudian, peneliti memberikan post-test pada kelas kontrol pada tanggal 29 September 2020 pada hari selasa, pukul 08.00 sampai dengan 09.30 pagi hari. Post-test pada kelas kontrol peneliti langsung membagikan puisi yang telah di sediakan dan menyuruh siswa untuk mempraktekkannya langsung di depan kelas dengan puisi yang berjudul 'Terima Kasih, Guru karya Chairil Anwar" kemudian siswa mempraktekkannya di depan temantemannya dengan memperhatikan unsurunsur dalam membaca puisi dengan benar dan tepat. Tujuan diterapkan post-test untuk melihat hasil akhir yang didapatkan siswa setelah dilakukan beberapa tahap, yaitu pretest dan materi membaca pusi. Ketika posttest dilakukan peneliti memberikan skor nilai yang sesuai dengan kriteria yang telah di tentukan dan memasukkannya kedalam tabel nilai. Berikut skor nilai tes akhir siswa (pretest) kelas kontrol.

Peneliti mencari nilai rata-rata menggunakan SPSS versi 18. Nilai rata-rata post-test yang diperoleh siswa adalah 70,68 lebih tinggi dari nilai pre-test sebelumnya, tetapi nilai post-test yang diperoleh siswa masih belum mencapai KKM yang ditentukan oleh guru disekolah. Dikarenakan pada kelas kontrol menggunakan metode konvensional (metode penemuan) banyak siswa yang merasa bosan dan tidak memperhatikan dan hanya sebagian siswa yang aktif dalam pembelajaran. Setelah diterapkan proses pembelajaran membaca puisi dengan menggunakan metode konvensional ditemukan bahwa tidak terjadi peningkatan nilai hasil belajar siswa materi membaca puisi.

\section{Deskripsi Proses Pembelajaran Kelas Eksperimen Menggunakan Media Audiovisual}

Seperti yang sudah diketahui hasil nilai ratarata yang diperoleh kelas kontrol pada saat pre-test adalah 65,68 dan post-test 70,68 hasil tersebut belum mencapai KKM sehingga metode konvensional yang dilakukan tidak terjadi peningkatan dalam pembelajaran membaca puisi. Penelitian selanjutnya dilakukan pada kelas VIII/D yang menjadi kelas eksperimen dengan jumlah siswa 22 siswa. Penelitian pre-test ini dilakukan pada tanggal 1 Oktober 2020 pada hari Rabu, pukul 11.00 sampai dengan pukul 12.30 siang hari. Pada kelas eksperimen dilakukan sama seperti kelas kontrol pre-test sebelumnya. Sebelum diberikan pre-test peneliti bertanya kepada siswa puisi apa saja yang sering mereka baca. Kemudian, peneliti memancing siswa tentang penyair-penyair yang hebat. Tujuan diterapkan pre-test untuk mengetahui kemampuan awal siswa dalam membaca puisi sebelum diberikan materi membaca puisi dengan benar dan tepat.

Pada saat pre-test berlangsung suasana kelas selama proses pre-test sama seperti siswa di kelas kontrol siswa terlihat kebingungan dalam melakukan pembacaan puisi, siswa merasa ragu dalam mengapreasikan bentuk vocal, irama intonasi dan ekpresi dalam membaca puisi. Dikarenakan siswa kurang mengetahui dan memahami bagaimana unsur pembacaan puisi yang benar dan tepat bahkan siswa juga tidak pernah melihatnya langsung bagaimana puisi yang di bacakan oleh seorang penyair. Setelah pre-test dilaksanakan kemudian peneliti memberi skor nilai terhadap hasil pre-test siswa dan dimasukkan ke dalam tabel nilai. Berikut skor kriteria nilai tes awal siswa (pre-test) kelas eksperimen.

Mencari nilai rata-rata pre-test pada kelas eksperimen sama seperti kelas sebelumnya. Peneliti mencari nilai rata-rata menggunakan SPSS versi 18, cara lain untuk mencari nilai rata-rata siswa dengan menggunakan rumus:

$$
\bar{X}=\frac{1}{n} \sum_{i=1}^{n} x i
$$

Keterangan:

$\bar{x}=$ rata-rata hitung

$x i=$ nilai sampel ke- $i$

$n=$ jumlah sampel

Nilai rata-rata dari pre-test kelas eksperimen adalah 69,55. Hasil pre-test yang diperoleh siswa lebih rendah dari nilai pretest kelas kontrol dan tidak memenuhi KKM. Atas dasar nilai pre-test tersebut, diterapkanlah metode audiovisual pada kelas eksperimen ini untuk melihat apakah terjadi peningkatan nilai hasil belajar terhadap keterampilan membaca puisi. Kemudian proses pembelajaran kelas eksperimen menggunakan metode media audio visual 
dilakukan pada tanggal 02 Oktober 2020 pada hari Kamis, pukul 10.00 sampai dengan pukul 11.30. Peneliti mengajarkan materi membaca puisi kepada siswa, peneliti menampilkan contoh video pembacaan puisi yang di lakukan oleh penyair hebat dengan puisi yang berjudul "Kepada Kawan Di Jalan Keheningan karya WS. Rendra" yang ditampilkan di depan kelas, semua siswa memperhatikan dan menyimak. Setelah video berakhir peneliti berinteraksi bersama siswa mengenai puisi ysng ada dalam video yang sudah ditampilkan.

Selanjutnya, setelah pre-test dan proses pembelajaran telah dilakukan. Peneliti memberikan post-test pada kelas eksperimen, post-test dilakukan pada tanggal 02 Oktober 2020 pada hari Kamis, pukul 08.30 sampai dengan 09.45 pagi hari. Peneliti menampilkan video membaca puisi yang berjudul "Kepada Kawan Di Jalan Keheningan Karya WS. Rendra" kemudian siswa membacakan kembali puisi yang diberikan oleh peneliti serta memperhatikan unsur-unsur yang terdapat dalam proses membaca puisi. Tujuan diterapkan post-test untuk melihat hasil akhir yang diperoleh siswa setelah diberikan pre-test (tes awal) dalam membaca puisi, kemudian siswa dimintai untuk maju kedepan dengan menampilkan puisi yang telah di berikan oleh peniliti dan di nilai dengan memberikan skor pada kriteria penelian masing-masing siswa dan dimasukkan ke dalam tabel nilai. Peneliti mencari nilai rata-rata menggunakan SPSS versi 18. Nilai rata-rata yang diperoleh siswa pada post-test sangat berbeda dari nilai pre-test sebelumnya. Nilai yang didapatkan adalah 83,64 sudah mencapai KKM. Dengan menggunakan metode media audiovisual siswa pada kelas eksperimen lebih aktif, lebih menyimak materi dan fokus dalam memperhatikan video yang ditampilkan peneliti. Sehingga dapat dikatakan membaca puisi dengan menggunakan metode media audiovisual mengalami peningkatan.

\section{Uji Prasyarat}

Uji prasyarat data dilakukan untuk menganalisis data yang telah didapatkan dalam penelitian. Data hasil penelitian akan diolah dengan uji hipotesis. Namun, sebelumnya akan dilakukan pengujian pra-syarat data yaitu uji normalitas dan uji homogenitas. Uji normalitas sebagai syarat untuk melakukan uji hipotesis.

Dasar pengambilan keputusan dalam uji normalitas adalah.

a) Jika Sig. atau nilai probabilitas < 0,05 maka data berdistribusi tidak normal.

b) Jika Sig. atau nilai probabilitas $>0,05$ maka data berdistribusi normal.

Berdasarkan tabel di atas nilai Sig. (2Tailed) pada shapiro-wilk nilai pre-test kelas eksperimen adalah sebesar 0,069, pre-test kelas kontrol sebesar 0,259, dan post-test kelas eksperimen sebesar 0,122 , post-test kelas kontrol sebesar 0,122. Hasil Sig. (2-Tailed) yang didapatkan menunjukkan bahwa hasil uji pre-test dan post-test berdistribusi normal, karena nilai $\operatorname{sig}>0,05$.

\section{Uji Homogenitas}

Uji homogenitas digunakan pada sampel yang telah ditentukan berdasarkan jumlah siswa kelas VIII/D sebagai kelas eksperimen (dengan model media audiovisual) dan siswa kelas VIII/E sebagai kelas kontrol (tidak menerapkan model media audiovisual). Jumlah sampel dari penelitian ini berjumlah 44 siswa. Jumlah itu merupakan gabungan dari kedua kelas eksperimen yang berjumlah 22 siswa dan kontrol berjumlah 22 siswa. Uji homogenitas ini dilakukan untuk mengetahui apakah kedua sampel penelitian bersifat homogen atau tidak. Data yang digunakan dalam uji homogenitas dalam penelitian ini berupa nilai hasil pre-test dan post-test kelas eksperimen dan kelas kontrol. Perhitungan uji homogenitas ini dilakukan dengan menggunakan program SPSS versi 18. Setelah semua data sampel berdistribusi normal, selanjutnya mencari varians pre-test dan post-test dari 
kedua kelompok tersebut. Kriteria penyajian data homogenitas, yaitu.

a) Jika probabilitas $>0,05$ maka $\mathrm{Ho}$ diterima artinya kedua data dinyatakan bersifat homogen.

b) Jika probabilitas < 0,05 maka $\mathrm{Ha}$ ditolak artinya varians dinyatakan heterogen.

Berikut kurva hasil dari uji humogenitas pre-Test dan post-Test dari kelas eksperimen maupun kelas kontrol.

Pengujian hasil homogenitas pada penelitian ini untuk mengetahui apakah kedua sampel mempunyai varians homogen atau heterogen. Pengujian homogenitas pada penelitian ini dilakukan dengan dua tahapan. Tahap pertama dilakukan pengujian homogenitas dari hasil nilai pre-test kelas eksperimen dan kelas kontrol. Tahap kedua dilakukan pengujian homogenitas dari hasil post-test kelas eksperimen dan kelas kontrol.

Nilai hasil pre-test kelas eksperimen dan kontrol mendapat hasil Sig. (2-Tailed) sebesar 0,475 dan posttest kelas eksperimen dan kontrol mendapat hasil Sig. (2-Tailed) sebesar 0,000. Hasil dari kedua tes yang dilakukan pada kelas eksperimen dan kontrol menunjukan bahwa kedua kelas bersifat homogen, karena Sig. > 0,05.

\section{Uji Hipotesis}

Uji hipotesis dilakukan setelah semua data terkumpulkan. Pengumpulan data pada penelitian ini berupa pre-test dan post-test keterampilan membaca puisi pada siswa kelas VIII SMPS Raudhatul Fuqara'. Terdapat dua hipotesis dalam penelitian ini, yaitu: Ha: Terdapat pengaruh yang signifikan dari media audiovisual terhadap keterampilan membaca puisi pada siswa kelas VIII SMPS Raudhatul Fuqara'. Ho: Tidak terdapat pengaruh yang signifikan dari media audiovisual terhadap keterampilan membaca puisi pada siswa kelas VIII SMPS Raudhatul Fuqara'. Uji hipotesis dalam penelitian ini menggunakan tabel group statistic dan independent sample test dengan bantuan program SPSS versi 18. Uji hipotesis dalam penelitian ini dibagi menjadi dua tahapan. Tahap pertama dilakukan uji hipotesis terhadap nilai pre-test dan post-test kelas kontrol untuk mengetahui ada tidaknya perbedaan nilai antara pre-test dan posttest kelas kontrol. Tahap kedua uji hipotesis terhadap nilai pre-test dan posttest kelas eksperimen untuk mengetahui ada tidaknya perbedaan nilai pre-test dan post-test pada kelas eksperimen.

Kedua hipotesis tersebut dapat dibuktikan dalam penelitian ini. Apabila nilai sig $<0,05$, maka $\mathrm{Ha}$ diterima. Berdasarkan hasil perhitungan yang diperoleh nilai $t$ sebesar $-5,669$ dan sig 0,000 artinya ada pengaruh yang signifikan dari penggunaa media audiovisual terhadap keterampilan membaca puisi, berdasarkan hasil nilai dari pre-test dan post-test kelas eksperimen dan kelas kontrol. Sedangkan, jika sig $\geq 0,05$, maka Ha ditolak dan Ho diterima. Berdasarkan dari hasil perhitungan yang diperoleh nilai $\mathrm{t}$ sebesar -1,891 dan sig 0,66 artinya ada peningkatan terhadap kedua kelas tersebut, namun pada proses melakukan penggunaan model media audio visual terhadap keterampilan membaca puisi yang diperoleh dari hasil pre-test dan post-test kelas eksperimen dan kelas kontrol terjadi pengaruh yang signifikan antar dua kelas tersebut.

\section{1) Uji Hipotesis Nilai Pre-Test dan Post-Test Kelas Kontrol}

Uji hipotesis nilai pre-test dan post-test pada kelas kontrol untuk mengetahui ada tidaknya perbedaan hasil pre-test dan post-test. Apabila tidak terdapat perbedaan pre-test dan post-test maka $\mathrm{Ha}$ ditolak dan Ho diterima, sebaliknya apabila terdapat perbedaan maka $\mathrm{Ha}$ diterima dan Ho ditolak. Hasil analisis uji hipotesis menunjukan bahwa nilai $\mathrm{t}$ sebesar -1,891 dan sig. 0,66 dan nilai sig $\geq 0,05$ maka dapat disimpulkan $\mathrm{Ha}$ diterima dan Ho ditolak, artinya ada 
perbedaan yang signifikan nilai hasil pretest dan post-test pada kelas kontrol. Berdasarkan penjelasan di atas, dapat dikatakan bahwa keterampilan yang dimiliki siswa pada saat pre-test dan posttest sedikit meningkat.

\section{2) Uji Hipotesis Nilai Pre-Test dan Post-Test Kelas Eksperimen}

Uji hipotesis nilai pre-test dan posttest kelas eksperimen untuk mengetahui ada tidaknya perbedaan nilai pre-test dan post-test. Apabila tidak terdapat perbedaan diantara pre-test dan post-test, maka Ha ditolak dan Ho diterima, sebaliknya apabila terdapat perbedaan maka Ha diterima dan Ho ditolak. Hasil analisis uji-t menunjukkan nilai t sebesar $-5,669$ dan sig 0,000. Nilai sig menyatakan < 0,05 maka dapat disimpulkan Ho ditolak dan Ha diterima. Sehingga dapat disimpulkan bahwa, terdapat perbedaan yang signifikan antara nilai rata-rata kemampuan menulis cerita ulang biografi kelas eksperimen yang menggunakan model media audiovisual.

\section{PEMBAHASAN}

Berdasarkan perhitungan di atas menunjukkan bahwa kelompok eksperimen lebih mudah dalam melakukan kegiatan membaca puisi dibandingkan dengan kelompok kontrol. Hal ini disebabkan keterampilan membaca puisi pada kelompok eksperimen dilakukan dengan bantuan media audio visual yang menampilkan video pembacaan puisi. Proses penggunaan media audio visual diawali dengan mengajak siswa menonton pemutaran video pembacaan puisi sebelum kegiatan membaca puisi. Setelah selesai menyimak video pembacaan puisi, siswa diajak mendiskusikan puisi tersebut. Kendala siswa dalam membaca puisi dapat diatasi dengan penggunaan media audio visual berupa penayangan video pembacaan puisi. Hal ini sangat berbeda dengan siswa kelompok kontrol yang mendapat pembelajaran tanpa menggunakan media audio visual berupa video pembacaan puisi, sehingga menimbulkan rendahnya skor keterampilan membaca puisi yang di dapatkan. Hal tersebut tidak hanya dikarenakan kesulitan dalam pemahaman puisi, melainkan juga diakibatkan kejenuhan siswa terhadap pembelajaran membaca puisi yang terlalu monoton dan membosankan.

Berdasarkan hasil pengamatan selama pembelajaran, praktik yang dilakukan secara terus menerus tanpa adanya variasi pembelajaran menimbulkan kebosanan pada siswa. Lain halnya dengan kelompok eksperimen yang menggunakan media audio visual yang menampilkan video pembacaan puisi, sehingga hal tersebut akan lebih menarik perhatian siswa dan siswa akan lebih termotivasi dalam membaca sebuah puisi. Data tersebut menunjukkan bahwa terdapat perbedaan yang signifikan antara kemampuan awal dan akhir keterampilan membaca puisi pada kelompok eksperimen. Dengan kata lain, terdapat peningkatan hasil skor yang signifikan setelah diberi perlakuan dengan menggunakan media audio visual. Berdasarkan hal itu dapat disimpulkan bahwa penggunaan media audio visual dalam keterampilan membaca puisi lebih efektif dari pada pembelajaran tanpa menggunakan media audio visual.

Pembahasan Hasil Penelitian Berdasarkan pengujian hipotesis yang telah dilakukan diperoleh hasil bahwa thit berada diluar daerah penerimaan $\mathrm{H} 0$ atau dengan kata lain H0 ditolak. Dengan demikian, hipotesis alternatif (Ha) yang menyatakan bahwa rata-rata hasil belajar membaca puisi siswa yang diajar dengan menggunakan media pembelajaran audiovisual lebih tinggi dibandingkan dengan tanpa menggunakan media pembelajaran audiovisual diterima pada taraf signifikan 5\%. Hal ini berarti terdapat pengaruh pembelajaran menggunakan media pembelajaran audiovisual terhadap hasil belajar Bahasa 
Indonesia, dalam hal membaca puisi. Di mana pengaruhnya merupakan pengaruh yang positif.

Adanya perbedaan rata-rata hasil belajar membaca puisi siswa pada kedua kelas tersebut disebabkan karena perbedaan perlakuan pada saat proses pembelajaran yang dilakukan, proses pembelajaran siswa pada kelas kontrol tanpa menggunakan media pembelajaran audiovisual dimana siswa langsung diminta untuk membacakan puisi yang telah ditentukan di depan kelas. Sementara proses pembelajaran siswa pada kelas eksperimen menggunakan media pembelajaran audiovisual, yakni dengan menampilkan video para penyair terlebih dahulu sebelum siswa tersebut diminta untuk membacakan puisi di depan kelas. Sehingga siswa memupunyai bayangan atau gambaran tentang membaca puisi yang baik dan benar.

\section{PENUTUP}

Berdasarkan pada perolehan data di lapangan melalui rangkaian penelitian, pengolahan data, serta menjawab hipotesis penelitian maka diperoleh kesimpulan akhir untuk menjawab pertanyaan penelitian mengenai bagaimana pengaruh media audiovisual terhadap kemampuan membaca puisi siswa kelas VIII SMPS Raudhatul Fuqara'. Berdasarkan hasil analisis terhadap hasil pembelajaran dan perhitungan statistik diketahui bahwa pengaruh media audiovisual terhadap keterampilan membaca puisi siswa kelas VIII SMPS Raudhatul Fuqara' menunjukkan hasil positif yaitu berpengaruh terhadap siswa dengan penggunaan media audio visual. Hal ini dibuktikan dengan perolehan nilai siswa kelas eksperimen (kelas yang menggunakan media audiovisual) lebih besar jika dibandingkan dengan kelas kontrol yang tidak menggunakan media audiovisual.
Berdasarkan kesimpulan di atas, maka sebagai tindak lanjut penelitian ini perlu dikemukakan beberapa saran yaitu: (1) Para guru Bahasa Indonesia hendaknya memandang bahwa pembelajaran membaca puisi merupakan bagian yang penting dan tidak terpisahkan dari mata pelajaran Bahasa Indonesia, sehingga kita perlu memperhatikan kemampuan siswa dalam membaca puisi yang baik. (2) Para guru Bahasa Indonesia hendaknya lebih bervariasi dalam memilih teknik dan media pembelajaran membaca puisi agar siswa memiliki minat mengikuti proses pembelajaran dan menghilangkan kesan bahwa pembelajaran puisi itu menjenuhkan. (3) Salah satu alternatif dalam menggunakan media pembelajaran puisi adalah penggunaan video tentang contoh pembacaan puisi yang dilakukan oleh penyair yang telah terbukti dapat meningkatkan kemampuan membaca puisi dan membuat pembelajaran membaca puisi menjadi menyenangkan

\section{DAFTAR PUSTAKA}

Arikonto, Suharsimi. (2013). Prosedur Penelitian Suatu Pendekatan Praktik. Jakarta: PT Rineka Cipta.

Farisah. (2017). 'Penerapan Media Vidio Untuk Meningkatkan Hasil Belajar Siswa Pada Materi Haji Di MIN Jeureula Aceh Besar'. Skripsi. Darussalam-Banda Aceh: Universitas Islam Negeri Ar Raniry.

Sugiyono. (2017). Metode Penelitian Kuantitatif, Kuantitatif Dan $R$ \& $D$ Bandung: Alfabeta.

Sadiman Dkk. (2018). Media Pendidikan. Depok: Rajawali Pers.

Yaumi, Muhammad. (2018). Media \& Teknologi Pembelajaran. Jakarta: Prenadamedia Group. 